\title{
THE RELATIONSHIP OF FARMERS SOCIO-ECONOMIC CONDITIONS, THE ROLE OF CHAIRMAN OF GROUPS AND AUTHORS WITH THE INNOVATION LEVEL OF SUPER LEGOWO RICE CULTIVATION
}

\author{
Vitriawati, Anantanyu Sapja, Lestari Eny \\ Community Empowement Study Program, University of Sebelas Maret, Indonesia \\ *E-mail: wativtria@gmail.com
}

\begin{abstract}
This study aims to determine the level of adoption of lowland rice farmers to super Jajar Legowo rice cultivation, knowing the relationship between socio-economic factors of farmers, knowing the relationship between the role of farmer group leader and the role of agricultural extension officers with the adoption rate of Super Jajar Legowo rice cultivation. This study uses a quantitative approach with survey techniques in Jati Village and Suruh Kalang Village, Jaten District, Karanganyar Regency. The data collection techniques use interview methods, recording and observation. An overview of the socio-economic conditions of agriculture, most of the age of farmers are between 46 - 55 years old, the level of formal education in elementary and high school, mastery of paddy fields $0.26-0.35$ ha, have farming income $>5$ million $(37 \%)$ / planting season, dependents of farmer families $<3$ people, farming experience mostly> 20 years and non-formal education in 1 Planting Season 2 times. The relationship between farmer's assessment of the role of the leader of the farmer group (as legitimator) and the role of the head of the farmer group (as advisor) with the adoption level of innovative legowo super rice cultivation has a real positive relationship. The relationship between farmers' assessment of the performance of educators, dissemination, facilitation, supervision, and evaluation with the level of adoption of innovative legowo super rice cultivation has a real positive relationship.
\end{abstract}

\section{KEY WORDS}

Farmer socio-economic, extension performance, evaluation, innovation adoption.

Indonesia is a developing country that began to take over technology in agricultural development. The interest of the Indonesian people in the field of agriculture has diminished, especially for young people, so that technology is expected to be able to replace human power into mechanical power in terms of planting, land processing, harvesting and postharvesting. Increasing population growth leads to increasing food needs while the area of agricultural land is getting narrower so farmers must be able to increase food production through intensification of agriculture (increased productivity). The main challenges faced in efforts to increase food crops are: (1) Increased demand for rice in accordance with the increase in population, (2) Limited availability of world rice, and (3) Tendency in rising food prices (Ministry of Agriculture, 2016).

Agricultural technology innovation is needed for increasing productivity and food production. Extension agents as a "bridge" of information between the government, researchers and farmers, especially new innovations. Extension workers must be able to transfer knowledge about innovation to the target (farmers) so that farmers want to adopt the innovation. Weaknesses that are often encountered in counseling are generally caused by the inadequacy of field extension agents to provide professional services to farmers, this is due to the lack of extension workers in each village. Extension agents need the help of a farmer group leader to help convey information on innovation adoption to farmers because the farmer group leader acts as a model for members of a social system. The chairman of the farmer group is respected by its members, and is an embodiment of the use of new ideas that are successful. The role of group leader is to reduce uncertainty of new innovations because the group leader adopts the innovation first and then delivers the subjective assessment of the innovation to the members. 
Jajar legowo super rice cultivation is a new innovation for farmers. Rice technology jajar legowo (jarwo) super is an integrated rice cultivation technology based on legowo row cultivation methods. Rice technology Jarwo Super uses: (1) quality seeds of new highyielding varieties with high yield potential, (2) biodecomposers during tillage, (3) biological fertilizers as balanced seed treatment and fertilization, (4) techniques for controlling plant disturbing organisms (OPT ) in an integrated manner, and (5) agricultural machinery especially for planting and harvesting (Ministry of Agriculture, 2016). The jajar legowo planting system has been introduced since 2008 in Karanganyar Regency, but farmers are still difficult to implement in the field because of the difficulty of finding planters who are able to plant rice with legajar jajar cropping patterns, and planting legowo jajar farmers think they spend higher costs. The Legowo jajar planting system is expected to replace the plot planting system that has been used by farmers in Indonesia. Farmers are still hesitant in applying paddy cultivation to super legowo in their paddy fields, rice is often pulled back after being planted with legowo rows and then planted with a plot planting system.

\section{METHODS OF RESEARCH}

This research was conducted in Karanganyar District, Central Java Province. The location of the study was done purposively because Karanganyar District was one of the central districts of wetland rice in Central Java.

\begin{tabular}{|c|c|}
\hline X1. Farmer's age & \\
\hline $\mathrm{X} 2$. Formal education level & \\
\hline $\mathrm{X} 3$. Land area & $\begin{array}{l}\text { Level of Adoption of Super Jajar } \\
\text { Legowo Rice Paddy Innovation }\end{array}$ \\
\hline X4. Farming Income & $\begin{array}{l}\text { Use of the New Superior } \\
\text { Variety high yield }\end{array}$ \\
\hline X5. Large family expenses & $>$ Use of Biodecomposer \\
\hline X6. Farming experience & fertilizers as seed \\
\hline X7. Non-formal education & $\begin{aligned} & \text { fertilization } \\
> & \text { Control of Plant }\end{aligned}$ \\
\hline $\begin{array}{l}\text { X8. Role of Group Chair } \\
>\text { Legistimator } \\
>\text { Advisor }\end{array}$ & $\begin{array}{l}\text { Disturbing Organisms } \\
\text { Use of agricultural tools } \\
\text { and machines }\end{array}$ \\
\hline
\end{tabular}

X9. Role of Extension

$>$ Education (Facilitating)

$>$ Desimination

> Facilitation (Mentoring)

> Supervision (Coaching)

$>$ Evaluation (Assessment)

Figure 1 - Relationship of Farmers' Socio-Economic Condition, Role of Chair of Group and Role of the Extension Staff with Adoption Level of Innovation in Sawah Jajar Legowo Super Rice Cultivation

The selection of Jaten District was done by purposive sampling because the District of Jaten was a sub-district that implemented a super legowo system. This research method uses survey research. A distinctive feature of this research is the data collected using a questionnaire. The unit of analysis of this study is farmers who cultivate rice (Oryza sativa) 
using the Jajar Legowo planting pattern 2. The study population was all rice paddy farmers who used the legowotype 2 cropping pattern. Sampled villages were Jati Village and Suruh Village Kalang because the village has implemented the Jajar Legowo Super rice cultivation with the highest number of farmers. The number of rice paddy farmer samples with Jajar Legowo Super planting pattern in Jaten sub-district is 60 people. Analysis of statistical data in this study using non-parametric statistical analysis techniques. The formula used is the Rank Spearman correlation coefficient (rs).

Formula: The formula used is as follows:

$$
r_{x y=} \frac{6 \sum D^{2}}{N\left(N^{2}-1\right)}
$$

Where: $r h o_{x y}=$ Spearman Rank Correlation Coefficient; $\mathrm{D}=$ Difference (differences between rank level); $\mathrm{N}=$ Number of respondents; The significance level of this study used a significance level of $5 \%$ and a level of confidence or confidence level of $95 \%$.

To obtain the required data, researchers use data collection techniques, namely interviews or recording interviews and observations. The measuring instrument or main instrument used in this study is a questionnaire

Analysis of statistical data in this study using non-parametric statistical analysis techniques. The significance of the relationship between the influence variables and the affected variables is used non-parametric analysis. The formula used is the Rank Spearman correlation coefficient (rs).

\section{RESULTS AND DISCUSSION}

Karanganyar Regency is one of the districts in Central Java Province which borders Sragen Regency in the north, East Java Province in the east, Wonogiri and Sukoharjo Districts and Boyolali District in the west (BPS, 2015).

The area of Kranganyar Regency is $77,378.64 \mathrm{Ha}$, which consists of paddy field area of $22,340.45 \mathrm{Ha}$ and dry land area of $55,038.19 \mathrm{Ha}$. Rice fields consist of technical irrigation 19,212.51 ha, non-technical 1,895.60 ha and non-irrigated 1,232.34 ha (BPS, 2015).

The agricultural sector in Jaten Subdistrict is not the main support of the economy. Of food crops that give the largest contribution are rice plants with a proportion of 100 percent of total production.

Farmer's Socio-Economic Condition. Most of the age of respondents indicated that the age of respondents aged 46 - 55 years as many as 27 people (45\%), respondents aged> 56 years as many as 24 people (40\%), aged 36 - 45 years as many as 12 people (12\%), and aged between 26 - 35 years as many as 2 people (3\%).

The education level of the respondents' farmers was calculated based on how many years they attended formal education. The results of the primary data analysis showed that most respondents only reached elementary school as many as 20 people (33\%), high school as many as 20 people (33\%), junior high school as many as 14 people (24\%) and did not complete elementary school 4 people $(7 \%)$ and graduated 2 universities (3\%).

The farmer's cultivated land area was calculated based on the paddy field area which was really worked out by the farmers. The results of the primary data analysis showed that the majority of respondents in the control of paddy fields were $0.26-0.35$ ha as many as 25 people $(42 \%)$, control of paddy fields $0.46-0.55$ as many as 19 people $(31 \%)$, control of paddy fields $<0,25$ ha as many as 12 people $(20 \%)$, and control of paddy fields $0.36-0.45$ ha as many as 4 people $(7 \%)$.

The income of farmer respondents is calculated based on the income of respondents from lowland rice farming. The income of farmer respondents mostly income $>5$ million as many as 22 people (37\%), income 3.1 million - 4 million as many as 10 respondents $(17 \%)$, farming income 4.1 million - 5 million as many as 9 respondents (15\%) income level of less 
than 2 million rupiah per planting season as many as 14 respondents (23\%) and income of 2 million - 3 million per planting season as many as 5 respondents (8\%).

The size of the family dependents is calculated based on the number of families that really are still borne by the family head. Most of the respondent farmers have family responsibilities of less than 3 people per family of 25 people (42\%), farmers who have less family responsibilities between 3-4 people per family as many as 23 people (38\%), family dependents 5-6 people as many as 11 farmers (18\%) while farmers who have family dependents $7-8$ as many as 1 respondent $(2 \%)$.

The farming experience of farmer farmers is the length of time the respondent farmers started cultivating lowland rice farming and calculated in units of years. Respondents mostly experience farming experience in> 20 years with 37 people (61\%), 16 - 20 years of farming experience, 10 people $(17 \%),<5$ years of rice farming experience $<6$ people $(10 \%), 5-10$ years of farming experience as many as 4 people $(7 \%)$ and $11-15$ years of rice farming experience in 3 years (5\%).

Non-formal education is calculated based on the frequency of counseling / meetings in one planting season. Farmers non-formal education responds to the majority of respondents doing 2 times non formal training / education (38\%), respondents doing training / education more than 3 times as many as 16 people (27\%), respondents who did 3 times as many trainings as 10 people $(17 \%)$ and those who conducted 1 time training were 11 people $(18 \%)$.

The role of the group leader is to direct its members in carrying out a group activity to achieve a common goal, namely the adoption of innovative rice cultivation in line with super legowo. The role of the group leader consists of:

- Legitimators are calculated based on frequency to strengthen or justify the existence of useful innovations for farmers;

- Advisors are calculated based on frequency giving guidance and direction to farmers if farmers experience difficulties in implementing innovation adoption.

Respondent farmers stated the frequency of the role of the group leader as a legitimator, most farmers answered often as many as 27 people $(46 \%)$, often 20 people (33\%), sometimes 8 people $(13 \%)$ and almost never 5 people $(8 \%)$ The head of the farmer group in providing information about innovation, they also adopted the innovation on their farm so that the farmers obtained the legitimacy of the innovation, one of them was from the group leader whether the innovation was useful or not.

Respondent farmers stated that the frequency of the role of group leaders as advisors, most often 29 people $(48 \%)$, often 22 people $(37 \%)$, almost never 6 people $(10 \%)$ and sometimes 3 people (5\%). Farmers in adopting the innovation of legowo super lowland rice cultivation often face problems due to lack of knowledge of farmers so farmers often ask the group leader and farmer group leader to give advice to farmers based on technical instructions or information from extension agents and other agricultural stakeholders.

The role of extension agents in addition to disseminating information must also be able to "persuade" farmers so that the latest technological innovations can be implemented and adopted. Farmers respondent stated the frequency of extension workers in facilitating the learning process and how to deliver in the learning process (education) most of the respondents stated that they were often 31 people $(45 \%)$, often 22 people (37\%), sometimes 4 people $(13 \%)$, almost never 2 people $(3 \%)$, and never 1 person $(2 \%)$. The frequency of extension agents in the dissemination of technology (dissemination) through the media, most of the respondents stated that they were often 36 people $(60 \%)$, often 20 people $(33 \%)$, sometimes 2 people (3\%), almost never 1 person (2\%), and never 1 person (2\%). The frequency of extension agents in providing facilities (facilitation) includes the frequency of meeting the needs of facilities and the complete needs of facilities, most of the respondents stated often as many as 33 people (55\%), often 24 people $(40 \%)$, never 2 people $(3 \%)$ and sometimes 1 person (2\%). Frequency of counselor in supervising (supervision), most of the respondent farmers stated that they were often 44 people $(73 \%)$, often 13 people $(22 \%)$, never 2 people $(3 \%)$ and sometimes 1 person $(2 \%)$. The frequency of extension agents in conducting evaluations before, during and after the activity is carried out (evaluation) 
includes whether the extension agent evaluates most of the respondent farmers stated that they were often 49 people (82\%), often 8 people (13\%), never 2 people $(3 \%)$ and almost never 1 person $(2 \%)$.

Level of Adoption of Super Innovation in Super Jowo Legowo Rice Cultivation. The farmer's adoption level regarding the application of the super-legowo super rice cultivation innovation is expressed by the score of the number of values of the application of rice cultivation technology in the ranks of super legoos grouped into three categories. Value 1 means the adoption rate is low, value 2 means adoption medium, and value 3 means the level of adoption is high. all assessments are based on technical guidelines (technical guidelines) for rice cultivation in the ranks of super legowo. The maximum value of 20 items is 60 with the lowest value is 0 . For category I values 0 - 20 means that the adoption rate is low, category II values 21-40 means moderate adoption rates and category III values 41 - 60 means high adoption rates.

Table 1 - Respondents Farmer's Distribution Based on Adoption Levels About Super Innovation of Jajar Legowo Rice Cultivation

\begin{tabular}{|c|c|c|c|c|c|}
\hline No & Adoption Level & Score & Criteria & $\begin{array}{l}\text { Number } \\
\text { of people }\end{array}$ & $\begin{array}{l}\text { Percentage } \\
\quad(\%)\end{array}$ \\
\hline 1. & Use of New Superior Varieties & $\begin{array}{c}9-12 \\
5-8 \\
1-4\end{array}$ & $\begin{array}{l}\text { High } \\
\text { Midle } \\
\text { Low }\end{array}$ & $\begin{array}{l}60 \\
- \\
-\end{array}$ & $\begin{array}{c}100 \\
- \\
-\end{array}$ \\
\hline 2. & Use of biodecomposers & $\begin{array}{l}5-6 \\
3-4 \\
1-2\end{array}$ & $\begin{array}{l}\text { High } \\
\text { Midle } \\
\text { Low }\end{array}$ & $\begin{array}{c}53 \\
2 \\
5\end{array}$ & $\begin{array}{c}89 \\
3 \\
8\end{array}$ \\
\hline 3. & $\begin{array}{l}\text { The use of biological fertilizers as seed treatment and } \\
\text { balanced fertilization }\end{array}$ & $\begin{array}{c}11-15 \\
6-10 \\
1-5\end{array}$ & $\begin{array}{l}\text { High } \\
\text { Midle } \\
\text { Low }\end{array}$ & $\begin{array}{c}54 \\
6 \\
-\end{array}$ & $\begin{array}{l}90 \\
10 \\
-\end{array}$ \\
\hline 4. & Control of Plant Disturbing Organisms (OPT) & $\begin{array}{c}9-12 \\
5-8 \\
1-4\end{array}$ & $\begin{array}{l}\text { High } \\
\text { Midle } \\
\text { Low }\end{array}$ & $\begin{array}{c}60 \\
- \\
-\end{array}$ & $\begin{array}{c}100 \\
- \\
-\end{array}$ \\
\hline 5. & Use of tools and agricultural machinery & $\begin{array}{c}11-15 \\
6-10 \\
1-5\end{array}$ & $\begin{array}{l}\text { High } \\
\text { Midle } \\
\text { Low }\end{array}$ & $\begin{array}{l}39 \\
21 \\
-\end{array}$ & $\begin{array}{c}65 \\
35 \\
-\end{array}$ \\
\hline
\end{tabular}

Source: Primary Data Analysis.

Relationship between Farmers' Socio-Economic Condition and the Level of Adoption of Innovation in Super Jajar Legowo Rice Cultivation. The relationship between the socioeconomic conditions of farmers and the level of adoption of innovative super legowo rice cultivation will be explained in this table.

Table 2 - Statistical Test Results Relationship Relationship of Farmers' Socio-Economic Condition, Role of Chair of Groups and Roles of Extension Workers with the Level of Adoption of Innovation in Super Legowo Paddy Cultivation

\begin{tabular}{|c|l|c|c|}
\hline \multirow{2}{*}{ Number } & \multirow{2}{*}{$\begin{array}{c}\text { Variable of Farmer Socio-Economic Condition, } \\
\text { Role of Chair of Farmer Group and Role of } \\
\text { Extension Officer }\end{array}$} & \multicolumn{2}{|c|}{$\begin{array}{c}\text { Level of Adoption of Super (Y) Jajar Legowo Rice Cultivation } \\
\text { Innovation }\end{array}$} \\
\cline { 3 - 4 } & \multicolumn{1}{|c|}{ rs } & t count \\
\hline 1 & Age (X1) & $-0,588$ & 5,122 \\
\hline 2 & Formal Education Level (X2) & 0,666 & 6,78 \\
\hline 3 & Area of Farmer's Land (X3) & 0,718 & 7,85 \\
\hline 4 & Farming Income (X4) & 0,731 & 3,16 \\
\hline 5 & Family Dependent (X5) & 0,454 & $-3,88$ \\
\hline 6 & Long Experience in Trying Farmers (X6) & $-0,369$ & 8,99 \\
\hline 7 & Non Formal Education (X7) & 0,763 & 7,51 \\
\hline 8 & Role of Group Chair (X8) & 0,702 & 7,18 \\
\hline 9 & Role of Instructor (X9) & 0,686 & \\
\hline
\end{tabular}

Source: Primary Data Analysis.

The relationship between the age of the farmer and the level of adoption of the innovation of super legowo jajar rice cultivation is a real negative relationship, this is indicated by the value of $r s=-0.588$ at $a=0.05$ with $t$ count of $5.122>t$ table 2.678 , meaning 
that with increasing age adoption rates are getting lower. Old age groups are passive in seeking information and are still very hesitant to try new innovations.

The relationship between the level of formal education of farmers and the level of adoption of the innovation of super legowo jajar rice cultivation is a real positive relationship, this is indicated by the value of $r s=0.666$ at $a=0.05$ with $t$ count $6.78>t$ table 2.678, meaning higher levels formal education the higher the level of adoption. Farmers with a high level of education will have broader insights so that they are more open to access to good information from various media so that they will open the way for someone who will make it easier to receive something new that is useful and willing to adopt innovations and will be easier in understand the intent and purpose of an innovation, instructions for use, guidebooks, etc.

The relationship between farmer's land area and the adoption rate of super legowo jajar rice cultivation innovation is a real positive relationship, this is indicated by the value of $r s=0.718$ at $a=0.05$ with $t$ calculated $7.85>t$ table 2.678 , means that the land area is owned the higher the level of adoption. Farmers with large land area will be more serious in optimizing production inputs as optimally as possible so that yields can be maximized. Large land area also makes it easier for agricultural machinery to run more optimally compared to smaller land areas so that with the presence of agricultural machinery.

The relationship between farmer's income and the level of adoption of innovative super legowo jajar rice cultivation is a real positive relationship, this is indicated by the value of $r s=$ 0.731 at $a=0.05$ with $t$ count of 8.16> t table 2.678, meaning higher the level of income will increase the level of adoption. Farmers with high income will make it easier to buy agricultural production facilities so that perfection in adoption can be realized. Availability of capital is a supporting factor for adopting innovation.

The relationship between the size of the family dependents and the level of adoption of the innovation of super legowo jajar rice cultivation is a real positive relationship, this is indicated by the value of $r s=0.454$ at $a=0.05$ with $t$ count of $3.88>t$ table 2.678 , meaning the greater dependents family, the higher the level of adoption. The large number of family dependents encourages a farmer to adopt because farmers can use their family members to be involved in super legowo rice cultivation such as planting, weeding, fertilizing, providing biological fertilizers, biodecomposers, controlling plant disturbing organisms and others.

The relationship between farming experience and the level of adoption of the innovation of super legowo jajar rice cultivation is a real negative relationship, this is indicated by the value of $r s=-0,369$ at $a=0.05$ with $t$ count 3.02> t table 2,678, meaning that the longer someone's farming experience, the lower the adoption level.

The relationship between the level of non-formal education and the level of adoption of the innovation of super legowo jajar rice cultivation is a real positive relationship, this is indicated by the value of $r s=0.763$ at $\alpha=0.05$ with $t$ count of $8.99>t$ table 2.678, meaning more following non-formal education, the higher the level of adoption. Farmers with a longer farming experience will feel that they are experienced in their fields.

The relationship between the role of group leader (as the legitimator and counselor) and the adoption rate of super-legowo super rice cultivation innovation is a real positive relationship with the level of adoption, this is indicated by the value of rs $=0.702$ at $\alpha=0.05$ with $t$ count $7.51>t$ table 2,678, means that the more often the farmer group leader gives guidance, the explanation of the legowo super rice cultivation is the higher the adoption level and the more often the farmer group leader accompanies each activity and responds and advises every problem in applying rice cultivation. high level of adoption.

The relationship between the role of extension agents and the adoption rate of super legowo superficial rice cultivation is a real positive relationship, this is indicated by the value of $r s=0.686$ at $a=0.05$ with $t$ calculated $7.81>t$ table 2.678 , meaning that the frequency of accompaniment is more frequent. learning process (education), technology dissemination (dissemination), facilitating farmers (facilitation), supervising, in evaluating before, during and after activities (evaluations) which are increasingly frequent, the higher the level of adoption. 


\section{CONCLUSION}

An overview of the socio-economic conditions of agriculture, most of the age of farmers between 46 - 55 years, the level of formal education in elementary and high school, mastery of paddy fields $0.26-0.35$ ha, farmers have farming income $>5$ million (37\%) / planting season. Most dependents of farming families $<3$ people. Farming experience is mostly $>20$ years and non-formal education includes education and training in 1 Planting Season 2 times. The relationship between farmer's age and farming experience with the level of adoption of legowo super rice cultivation innovations has a real negative relationship while the relationship between education levels formal farmers, farmer's land area, farming income, dependency of farmer families, and non-formal education level with the adoption level of innovation in paddy cultivation super legowo has a real positive relationship. Relationship between farmers' assessment of the role of farmer group leader (as legitimator) and chairman farmer groups (as advisors) with the level of adoption of innovative legowo super rice cultivation has a real positive relationship. The relationship between farmers' assessment of the performance of educators, dissemination, facilitation, supervision, and evaluation with the level of adoption of innovative legowo super rice cultivation has a real positive relationship.

\section{REFERENCES}

1. Bungin, Burhan, 2005. Metodologi Penelitian Kuantitatif. Kencana Prenada Media Group. Indonesia.

2. Lestari, Eny, 1994. Hubungan Status Sosial Ekonomi Petani Dengan Tingkat Adopsi Inovasi Sapta Usaha Pertanian (Studi Kasus Di Kecamatan Polanharjo Kabupaten Klaten Propinsi Jawa Tengah. Thesis. Institut Pertanian Bogor. Bogor

3. Direktorat Jenderal Tanaman Pangan, 2017. Pedoman Pelaksanaan Kegiatan 2017. Direktorat Jenderal Tanaman Pangan Kementrian Pertanian. Jakarta Selatan.

4. Kementerian Pertanian,Balai Penelitian and Pengembangan Pertanian,2013.Sistem Tanam Legowo.

5. Badan Penelitian and Pengembangan Pertanian Kementrian Pertanian, 2016. Petunjuk Teknis Budidaya Padi Jajar Legowo Super.Kementrian Pertanian. Indonesia

6. Mardikanto, Totok,, 2009. Sistem Penyuluhan Pertanian. Lembaga Pengembangan Pendidikan (LPP) UNS and UPT. Penerbitan and Pencetakan UNS (UNS Press). Surakarta.

7. Heru Irianto, 2010. Metoda Penelitian and Evaluasi Agribisnis. Jurusan/ Program Studi Agribisnis Universitas Sebelas Maret Surakarta. Jawa Tengah.

8. Rogers, M. Everest, 1962. Difusi Inovasi (Penyebaran Ide-ide Baru Ke Masyarakat).The Free Press. New York.

9. 1983. Diffusion Of Innovations .Third edition.1983. The Free Press. New York.

10. Singarimbun, Masri and Sofian Effendi. 1989. Metode Penelitian Survai. PT. Pustaka LP3ES Indonesia, anggota IKAPI. Jakarta

11. Slamet, Yulius, 2008. Pengantar Penelitian Kuantitatif. Lembaga Pengembangan Pendidikan (LPP) UNS and UPT Penerbitan and Pencetakan UNS: UNS Press. Surakarta.

12. Suhardiyono, 1992. Penyuluhan: Petunjuk bagi Penyuluh Pertanian. PT Gelora Aksara Pratama. Erlangga. Jakarta.

13. Suryabrata, Sumadi, 1998. Pengembangan Alat Ukur Psikologis. Direktorat Jenderal Pendidikan Tinggi Departemen Pendidikan and Kebudayaan. Jalan Pintu Satu Senayan, Jakarta.

14. Zuriah, Nurul. 2005. Metodologi Penelitian Sosial and Pendidikan (Teori - Aplikasi). PT Bumi Aksara. Jakarta. 